\title{
Oktatásinformatika a felsőoktatásban - Kooperáció és párbeszéd a jó gyakorlatok megteremtésében
}

\author{
M. Pintér Tibor \\ Károli Gáspár Református Egyetem Bölcsészet- és Társadalomtudományi Kar \\ Magyar Nyelvtudományi Tanszék
}

\begin{abstract}
Absztrakt
Az oktatás digitalizációja nem újkeletű a magyarországi köz- és felsőoktatásban. A 2020-as év járványhelyzete miatt az online térbe került oktatás újabb folyamatokat indított meg az oktatás digitalizációja terén. A Károli Gáspár Református Egyetem még 2020 tavaszára szervezett egy, a felsőoktatás IKT-helyzetét felmérő konferenciát, amelyet a járvány miatt csak online és hónapokkal később tudott megrendezni. A konferencia előadásai és kerekasztal-beszélgetése nem tudta és nem is akarta megkerülni a járványhelyzetet, így a magyarországi felsőoktatás oktatásinformatikai helyzetének elemzése mellett a 2020-as pandémia alatt kialakult online oktatásra is reflektáltak.
\end{abstract}

Kulcsszavak: Covid19, oktatásinformatika, IKT, jó gyakorlatok

A 2020. évre a koronavírus-járvány éveként fogunk visszatekinteni. A vírushelyzet miatt újraértelmeződtek az emberi kapcsolatok, az oktatás-nevelés, a kutatás és valójában az élet szinte minden része. Az új élethelyzet teremtette kihívások megjelentek az oktatásban, illetve az oktatáspolitikában is. A Károli Gáspár Református Egyetem IKT Kutatóközpontja Oktatásinformatika a felsőoktatásban - Kooperáció és párbeszéd a jó gyakorlatok megteremtésében ${ }^{1}$ címmel 2020. november 20-án konferenciát szervezett, melynek fö témája a hazai felsőoktatás oktatásinformatikai lefedettsége, illetve a 2020ban kialakult Covid19-járvány miatt elrendelt digitális oktatás folyamán öszszegyült tapasztalatok több szempontú összegzése volt. A konferencia nem titkolt fó célja az volt, hogy párbeszédet kezdeményezzen az egyes érintett magyarországi felsőoktatási intézmények és felsőoktatás alakításáért felelős intézmények között, megalapozva az egyes résztvevők közti kapcsolat kialakulását, elmélyülését. A konferencia négy egymástól elkülönülő, ugyanak-

${ }^{1}$ A konferencia online felülete: https://btk.kre.hu/konf/index.php/oktinfkonf_felsooktatas/ev2020/fooldal 
kor szervesen összefüggő részből állt: előadások, kerekasztal-beszélgetés, könyv- és kurzusbemutatók, illetve párhuzamos online workshopok.

A Covid19 hatása nem csak tematikusan jelent meg a konferencián: az eredetileg 2020 tavaszára tervezett esemény csak novemberben, illetve csak az online térben, Zoomon valósult meg.

A meghívott előadók az felsőoktatás oktatásinformatikai szakértői voltak. Az első előadó, Turcsányi-Szabó Márta $A$ felsőoktatás digitalizálása: múlt, jelen és jövő című előadásában a felsőoktatás digitalizálásáról, digitalizáltságáról beszélt, a közoktatástól kiindulva, de kiemelve tanárképzést, fókuszba hozva a technológia és a tanulás változásait, valamint a digitalizálás kapcsán felmerülő szakmódszertani fejlesztéseket. Előadásában a hazai felsőoktatás digitalizáltságát bemutató helyzetkép mellett megismerhettünk néhány nemzetközi, a tanulási és technológiai fejlődést érintő jógyakorlatot, valamint hallhattunk a távoktatás okozta „post-sokk” kutatásának módszertanáról. Előadásában kiemelte a tanárképzés kihívásalapú megközelítését, ahol az online térbe költözés jótékonyan befolyásolta az élményalapú oktatást (ehhez persze szükség volt, van a megfelelő technológia jelenlétére, a megfelelő módszertan használatára, valamint az oktatásban részt vevő felek irányából a flow meglétére). Az oktatás fejlesztését, fejlődését többek között ún. digitális élményközpontok felállításában látja, amelyek alternatív módon, digitális technológiákon keresztül próbálják közelebb hozni az oktatásban használt digitális technológiákat - oktatóknak, tanároknak, diákoknak, gyerekeknek és osztályoknak.

A folytatásban Perényi Petra A magyarországi felsőoktatás digitális fejlesztésének támogatása címmel megtartott előadása következett, amelyben az elöadó a Digitális Kompetencia Központ Digitális Jólét Programjáról számolt be. A résztvevők meghallgathatták a program történetét, mérföldköveinek fejlödését, a projekt elindulása óta felmutatható eredményeket, amelyek magukban foglalják a digitális infrastruktúra, a digitális kompetenciák, a digitális állam és a digitális gazdaság előremozdulásának egy-egy fontos állomását. A mérföldkövek között - a konferencia témájára tekintettel - kiemelt szerepet kapott a Digitális Oktatási Stratégia (DOS), amely fontos törekvése, hogy a magyar felsőoktatásban létrehozzon egy olyan egységes online, digitális környezetet, amely korra, érdeklődésre és egyéni élethelyzetre szabottan kínál személyre szabott tanulási lehetőségeket. A DOS célja egy olyan online tanulási tér, tanulási közösség létrehozása, ahol a közösség tagjai támogatást kapnak az egész életükön át tartó tanulásukhoz és fejlődésükhöz. Ezen törekvéseiket részben már a Covid19 miatt kialakult digitális oktatási helyzet alatt lehetőség volt kipróbálni, megmérettetni. A távoktatás megteremtette azt a digitális helyzetet, amely az alábbi három stratégiai cél megvalósításában is segíthet. Így az oktatás-tanulás jelenlegi módszertanának, megközelítésének átalakítása, amely a hallgatóközpontú tanuláson, az IKT-technológiák kiaknázásán keresztül paradigmaváltást hozhat a felsőoktatásban. A felsőoktatás kiemelt stratégiája egy, a hallgatókat és oktatókat egyaránt segítő, digitális eszközökkel 
támogatott tanulási tér és digitális tanulási közösség kiépítése, illetve a fejlesztéshez szükséges infrastruktúra karbantartása, hatékonyságnövelése. Az elöadás második részében az előadó rámutatott, hogy a célként kitüzött stratégiák egy része a Covid19 időszak alatt részben vagy egészében már megvalósult. Az előadás végén a távolléti oktatás előnyeit és kihívásait összegezve az előadótól megtudhattuk, hogy e néhány hónap alatt rugalmasabb lett az oktatás- és tanulásszervezés (így például ma már elképzelhető a jelenléti oktatás online platformon történő párhuzamos biztosítása). Nagy kihívás azonban továbbra is. hogy az oktatásnak vannak olyan elemei, amelyekben a személyes jelenlét hozzáadott értéke nem pótolható online felületen (például a gyakorlatok vagy a kapcsolódó beszélgetések „ereje”).

A konferenica utolsó „nagyelőadását” Ollé János tartotta Digitális kompetencia és digitális oktatási kultúra a felsőoktatásban címmel. Az előadásban a digitális oktatás jelentette kihívásokról beszélt, külön kiemelve a Covid-időszak gyors átállása miatt kialakultakat (mind oktatói, mind hallgatói oldalról). Előadásában hangsúlyozta, hogy a vírushelyzet kiváltotta digitális átállás hatékonysága a digitális oktatás, a felsőoktatás-pedagógia és a felsőoktatás-menedzsment összetett folyamatainak sikerességén múlt, múlik. Ennek kapcsán hangsúlyozta, hogy a digitális kompetenciafejlesztés oktatásbeli sikere csak az oktatási minőségfejlesztés részeként müködhet. Ugyanakkor azt is fontosnak tartja, hogy a digitális kultúra fejlesztését nem szabad azonosítani a Covid-időszak alatti kényszerű digitális átállással, mint ahogy azt is, hogy az oktatásban történő digitális kompetenciafejlesztés nem lehet egyoldalú, a siker kulcsa a hallgatói és oktatói narratíva együttes figyelembevétele.

A konferencia második pillére a Kerekasztal-beszélgetés a hazai felsőoktatás és felsőoktatásban részt vevő oktatók digitális kompetenciáiról elnevezésü kerekasztal-beszélgetés volt, amelyen az oktatásinformatikai fejlesztésekben élen járó hazai felsőoktatási intézmények (BCE, ELTE, CEU, BGE, KRE és EKE) képviselői vettek részt. A beszélgetés alapját képező kérdések a szervezeti egységek müködésének teljes spektrumát kívánták áttekinteni a megalakulástól és az alapvető feladatoktól kezdve a fejlesztés, megvalósítás jelenlegi lépésein át egészen a távlati tervekig, kitérve a müködő jó gyakorlatokra, valamint a nehézségekre, megoldandó problémákra egyaránt. A beszélgetés résztvevői hangsúlyozták, hogy a felsőoktatás digitalizálásában és az oktatók digitális kompetenciáinak fejlesztésében az intézményi támogatottság egyre meghatározóbb szerepet tölt be. Ennek hangsúlyos része a felsőoktatásban oktatók digitális kompetenciájának rendszeres és célorientált fejlesztése (ennek hatása, az egyes egyetemek közti különbségek érzékelhetőek voltak a távoktatás alatt), a megfelelő oktatói környezet, infrastruktúra biztosítása, a digitális eszközhasználatnak az intézmény vezetősége által történő, rendszerszintű támogatása. A beszélgetés folyamán a résztvevők az alábbi témákat érintették: Szervezeti felépítés, a legfontosabb funkciók, feladatok, Az oktatásinformatikai fejlesztés folyamata, annak főbb eszközei, formái, a fejlesztés során használt motivációs eszközök, valamint az intézményvezetői és a kormányzati támogatás szerepe a fejlesztés során. A beszélgetés vé- 
gén a résztvevők kitértek arra a kérdésre is, hogyan hatott a Covid19-járvány az egyes szervezeti egységek munkájára. Érintették technológiai fejlesztések és oktatásinformatikai képzésfejlesztés megvalósított módjait, a távolléti oktatáshoz kapcsolódóan végzett méréseket, elemzéseket, azok eredményeit, illetve kitértek az egyes intézmények infrastruktúrájának változásaira (a kerekasztal-beszélgetés eredményeiről bővebben $M$. Pintér et al. megj. alatt).

A délutáni folytatás központi témája a jó gyakorlatok megosztása, bemutatása volt. Elsőként $A$ felsőoktatói digitális kompetenciák fejlesztése: könyv- és kurzusbemutatók részben három bemutatót láthattak az érdeklődők: a sort a KRE IKT Kutatóközpontja nyitotta meg Az oktatásinformatika módszertana a felsőoktatásban c. kézikönyv bemutatójával. A kötet elsősorban a felsőoktatásban dolgozók digitális kompetenciáinak fejlesztését szolgálja - a DigCompEdu-keretrendszer alapján összeállított fejezetek, jó gyakorlatok és módszertani leírások mentén. A bemutató után az ELTE szervezésében $A$ METAMOOC - A nyílt kurzusok tervezésével foglalkozó nyillt kurzus bemutatója és tananyagterve$z o ̋ i$, facilitátori tapasztalatairól láthatott a közönség bemutatót. A bemutatott mooc-rendszer használatának aktualitását épp a járványhelyzet jelentette. Az ELTE által évek óta müködtetett rendszer, kurzus azoknak a pedagógusoknak, elsősorban egyetemi oktatóknak, középiskolai tanároknak szól, akik az online tanulás előnyeit kívánják tanítványaik számára kínálni, ezzel kapcsolatos ismereteiket bővíteni kívánják vagy csak ismerkednek a lehetőségeikkel. A harmadik, egyben záró bemutató a Tempus Közalapítvány munkatársaitól hangzott el, $A$ felsőoktatás minöségfejlesztésének online és offline eszközei, valamint $A$ tanulás jövője - Közösségi tér a pedagógusok tudásmegosztásáért címmel. Mindkét előadás a digitális oktatás előnyeiről, a felsőoktatás innovatív megközelítéséről szólt, kiemelve a Tempus Közalapítvány oktatásban végzett érdemeit.

A konferencia záró eseményeként az érdeklődő résztvevők online workshopokon vehettek részt: ezeken lemérhették, fejleszthették digitális kompetenciáikat.

A 2020 novemberében megszervezett Oktatásinformatika a felsőoktatásban konferenciasorozat első „állomása” ígéretes jövőt sejtet. A Covid19 által megvalósított, online térbe helyezett oktatás kihívásai hatással voltak az oktatásinformatikára, az oktatásinformatikai fejlesztésekre is. A következő konferencia remélhetően már egy nyugodtabb élethelyzet tapasztalatait mutathatja be.

\section{Irodalom}

M. Pintér, T., Bodnár, É., Dósa, K., Dorner, H., Lénárt, K., Lengyelné Molnár, T., Misic, G., Ollé, J., Rymarenko, M., Vörös, Z. \& Dringó-Horváth, I. (2021). Oktatásinformatikai helyzetkép a magyarországi felsőoktatásban. Új Pedagógiai Szemle, 71(03-04), 54-74. 


\section{Pintér, T.}

\section{Education informatics in higher education - Co-operation and dialogues in creating good practices}

The digitalisation of education of higher education in Hungary has a long history. But due to the Covid-epidemy in 2020, online education brought new processes in the digitization of education. In 2020 Károli Gáspár Reformed University organized a conference on digital pedagogy, which could be held only in on-line form and postponed months to the original plans. The lectures and roundtable discussion of the conference could not and did not want to bypass the epidemic situation, so in addition to the analysis of the educational informatics situation in higher education, participants also reflected on the online education developed during the 2020 pandemic.

Keywords: Covid19, education informatics, ICT, good practices

M. Pintér Tibor: https://orcid.org/0000-0002-5212-4107 